\title{
АНАЛІЗ ТА ВИКОРИСТАННЯ М'ЯСНОГО КЛАСТЕРУ В СІЛЬСЬКОГОСПОДАРСЬКІЙ ГАЛУЗІ
}

\author{
Усикова Олена Миколаївна \\ доктор економічних наук, доцент \\ Миколаївський національний аграрний університет (м. Миколаїв, Україна) \\ ORCID: 0000-0001-6734-5757 \\ usykova@mnau.edu.ua
}

У даній статті проведено аналіз та досліджено ефрективність кластерного підходу для розвитку промислового свинарства. В статті розроблено модель кластеру з розвитку свинарства, а також використано компенсаційно-витратний підхід та технологічний ланцюг виробництва. Досліджено входження в м'ясний кластер підприємств, аналіз сучасного стану розвитку ринка м'яса в Херсонській області. Результати дослідження показали, що ціни на окремі види м'яса не дозволяють сільськогосподарським товаровиробникам здійснювати не тільки розширене, а й просте відтворення.

Ключові слова: кластерний підхід, кластери, саморегульована організація, конкурентоспроможність, м'ясний кластер, компенсаиійно-витратний підхід, розподіл субсидій.

DOI: https://doi.org/10.32845/bsnau.2019.3.7

Постановка проблеми. Ефективність кластерного підходу полягає в можливості використання при створенні в регіонах нових потужностей для виробництва м'яса свиней шляхом кооперації, а також на основі поєднання державної підтримки з приватними інвестиціями. На сьогоднішній день поєднання держави та приватного сектору проходить досить важко через встановлення організаційно-правових форм, що потребує пошуку нових та швидких взаємозв'язків між цими двома сторонами.

Аналіз останніх досліджень і публікацій. Питання ефективності кластерного підходу в промисловому свинарстві, піднімаються в дослідженнях Пуцентейло П. Р., де він запропоновує концептуальні засади задля розвитку агропромислової галузі, а саме конкурентоспроможність та підвищення м'ясної промисловості в Україні[1]. Виявленням змін у пропорціях виробництва, споживання свинини у світі та регіонах займався К.М. Гірняк [2]. Займався вивченням організаційноекономічним розвитком підприємств та вніс свій вклад у м'ясну промисловість М.В. Калінчик [3]. Мазуренко О.В. досліджував інноваційні аспекти забезпечення соціально-економічної ефективності галузі свинарства[4]. Аналізу сучасного стану, проблем та перспектив розвитку сільського господарства присвятили свої праці дослідники В.Я. Месель-Веселяк [5], Н.В. Оляднічук [6], В.П.Рибалко [7] та ін. При цьому слід відзначити,що автори по-різному трактують об'єкти перевірки та дослідження.

Мета та завдання статті. Метою дослідження $є$ аналіз системи інтенсивного виробництва свинини на основі кластерного підходу з включенням у процес виробництва існуючих потужностей, а також визначення шляхів удосконалення окремих складових економічного механізму в сільськогосподарській галузі.

Виклад основного матеріалу. Сьогодні кластерний підхід визнаний на державному рівні одним із пріоритетів регіонального розвитку, що припускає поділ економіки країни не стільки по територіях, скільки за технологіями. При кластер-

ному підході у фокусі розвитку знаходиться не галузь, а сукупність промислових об'єктів і підприємств часто з абсолютно різних галузей, об'єднаних створенням спільного продукту і використанням спільних технологій.

Кластер з розвитку свинарства будується на принципах міжгалузевої та міжтериторіальної кооперації, а також на основі поєднання державної підтримки з приватними інвестиціями.

Оскільки кластери - «неформальні об'єднання», то і відносини в них не формалізовані і будуються, в значній мірі, на довірі, компетентності і сумлінності учасників[8]. В цьому випадку, до вже діючої моделі кластеру з розвитку свинарства в Херсонській області, можна віднести технологічний ланцюг виробництва та продажу готової продукції свинарства і формалізовані взаємини учасників кластера, споруджувані на встановлених стандартах і правилах ведення діяльності в рамках кластеру (рисунок 1).

В якості координуючого і сполучного елемента всіх учасників кластеру створити саморегульовану організацію, що складається з представників учасників центрів компетенції кластеру, що займається розробкою і встановленням стандартів і правил виробничої діяльності в рамках кластеру, а також контролем за дотриманням вимог таких стандартів i правил.

Додатково в якості учасників кластеру пропонується задіяти малі форми господарювання на селі - фермерські господарства (ФГ). Так, ФГ, що спеціалізуються на виробництві зернових, можуть бути задіяні на основі системи субконтракту в діяльності підприємств, які займаються випуском та переробкою зерна або підприємств з виробництва комбікормів. Окремі ФГ можуть бути задіяні на вирощуванні та відгодівлі свиней за договорами з відгодівельними підприємствами або підприємствами по забою свиней[9, с.86 ].

Ще одним центром компетенції в пропонованій моделі кластеру з розвитку свинарства в Херсонській області має стати наукове забезпечення діяльності всіх учасників кластеру. 


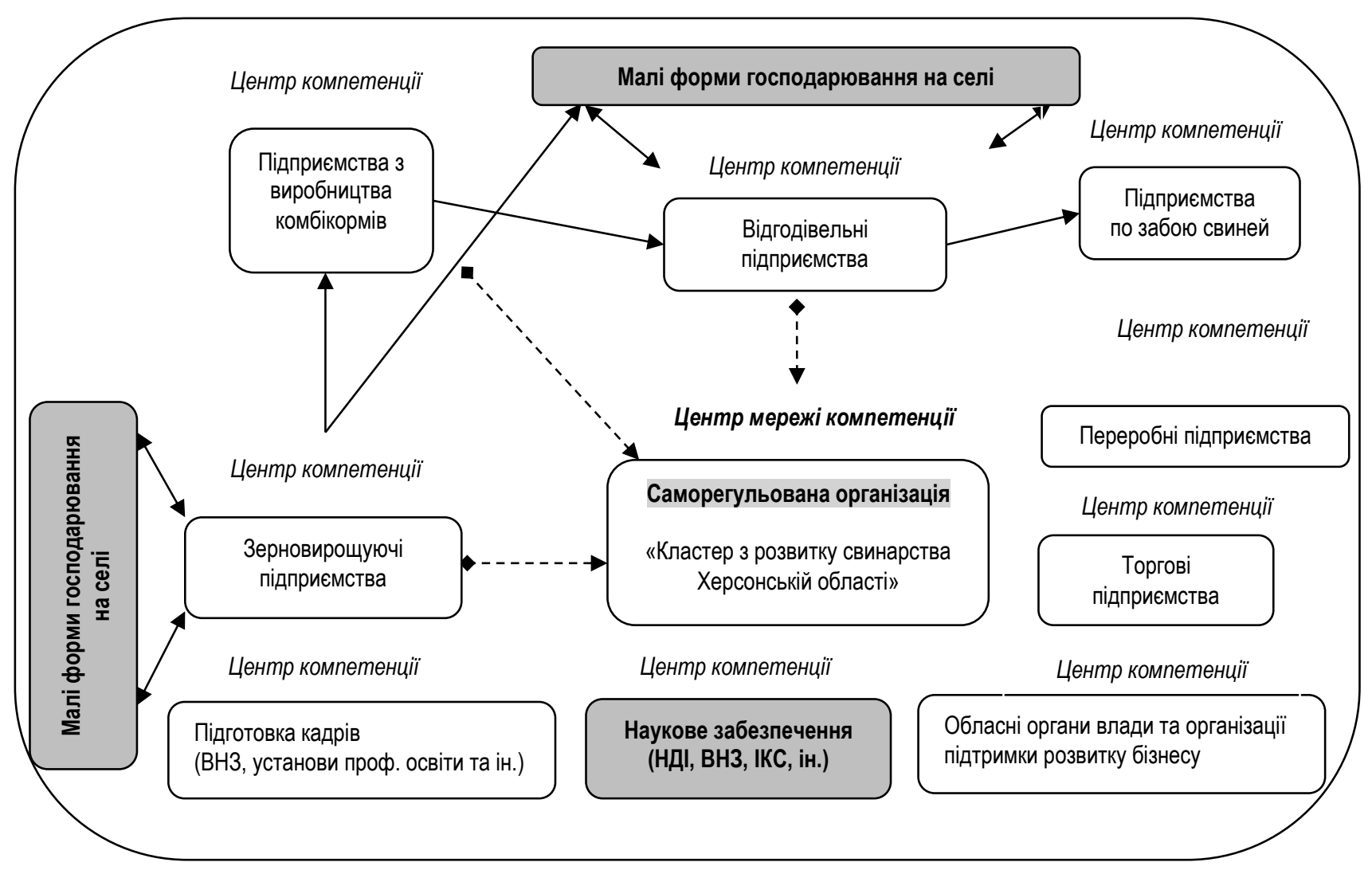

Технологічний ланцюг виробництва та продажу готової продукції свинарства

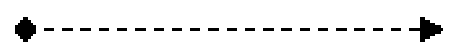

Формалізовані взаємини учасників кластера, споруджувані на встановлених стандартах і правилах ведення діяльності в рамках кластера

\section{Рис. 1 - Модель кластеру з розвитку свинарства в Херсонській області}

Зацікавленість в об'єднанні та співробітництво в рамках кластерного утворення проявиться, насамперед, у можливості поділу витрат і ризиків між учасниками кластеру, які можуть виявитися більш високими для підприємства поза кластером. Тому, всередині м'ясного кластеру необхідно розробити особливі схеми взаєморозрахунків між його учасниками, такі як обмін, розподіл доходів і т. д. Це сприятиме поліпшенню умов господарювання товаровиробникам м'яса, а також дозволить розширити сферу діяльності для інших учасників об'єднання, які не пов'язані безпосередньо з виробництвом та збутом м'яса.

Особлива роль в м'ясному кластері повинна відводитися торгово-фрінансовому блоку. Для підприємств, що входять в м'ясний кластер, необхідно розробити особливу схему надання фінансових послуг, суть якої повинна буде полягати в ефективному розподілі фінансових ресурсів всередині кластеру. Так, якщо відсотки за вкладами і позиками у кредитних організаціях м'ясного кластеру прирівняти до ставки рефінансування Центрального Банку, то це, безумовно, приверне увагу потенційних учасників кластеру, від яких, в свою чергу, буде потрібно здійснювати всі свої розрахунково-касові операції в кредитних організаціях кластеру.

Кредитний портфрель банківських структур кластеру доцільніше формувати за рахунок вкладів учасників кластеру, що захистить кредитні організації від додаткових ризиків, а, з урахуванням того, що відсотки по кредитах і внесках будуть рівні, викличе інтерес у позичальників, які матимуть можливість захистити свої фінансові ресурси від інфляяційних процесів.

Входження в м'ясний кластер підприємств, що здійснюють постачальницьку, обслуговуючу і торговельну діяльність, а також підприємств, чия діяльність не має прямих зв'язків з агропромисловим комплексом регіону, в перспективі, крім особливих схем взаєморозрахунків і стратегії розподілу фінансових ресурсів, сприяє відкриттю безлічі інших важливих можливостей. До них можна віднести:

- впровадження результатів науково-дослідних робіт;

- обмін досвідом та інформаційне забезпечення;

- вихід на нові ринки збуту;

- кадрове забезпечення та обмін кадрами;

- додаткову рекламу;

- спільну діяльність в здійсненні різних проектів.

Безумовно, перерахований список можливостей не $є$ вичерпним. Слід зазначити, що чимала роль у становленні м'ясного кластеру відводиться органам влади Херсонській області та державним службам, особливо при вирішенні питань і завдань, пов'язаних з державною підтримкою, розвитком інфраструктури, представленням інтересів на державному рівні влади і т. д.

Створення м'ясного кластеру виключно важливо при формуванні сучасного цивілізованого ринку м'яса на території Херсонської області з притаманною йому розвиненою інфраструктурою. При цьому стратегія, спрямована на створення міцної сировинної бази на ринку м'яса в Херсонській 
області шляхом підвищення ефективності його виробництва, заснована на тісному кооперуванні при активній діловій взаємодії, буде сприяти розвитку всіх складових м'ясного кластеру в Херсонській області та забезпечить необхідні конкурентні переваги перед іншими учасниками ринку.

3 метою обґрунтування необхідності посилення державного впливу на ринок м'яса Херсонській області, досліджені характер і ступінь державного впливу на діяльність основних суб'єктів цього ринку - сільськогосподарських товаровиробників.

Слід відзначити необхідність підвищення ефективності розподілу державної фінансової підтримки шляхом її перерозподілу з неефективних галузей економіки в найбільш перспективні з метою досягнення намічених результатів, зокрема з питання збільшення самозабезпеченості м'ясом.

Вступ України до СОТ вимагає пошуку особливих ме- тодів розподілу прямої державної підтримки, які значно вплинули б на зміну співвідношення собівартості та ціни реалізації на користь товаровиробників м'яса. В основі цих методів доцільним є поєднання двох чинників: визначення необхідного розміру субсидії товаровиробникам м'яса і її ефективного розподілу.

Удосконалення заходів державної підтримки товаровиробників м'яса набуває особливої актуальності в таких регіонах, як Херсонська область. Як показав алгоритм сучасного стану та перспектив розвитку ринку м'яса Херсонській області, попитом у населення регіону користується, насамперед, якісна продукція з м'яса місцевих сільськогосподарських товаровиробників, незважаючи на її ціну і упаковку (табл. 1). Крім цього, географічне розташування регіону та наявні внутрішні виробничі можливості дають місцевим товаровиробникам певні конкурентні переваги перед закордонними експортерами м'яса.

Таблиця 1

Алгоритм оцінки сучасного стану та перспектив розвитку регіонального ринку м'яса

\begin{tabular}{|c|l|}
\hline Найменування етапів дослідження & \multicolumn{1}{c|}{ Опис етапів дослідження } \\
\hline Місце і роль ринку м'яса в економіці країни & 1.Умови формування регіонального ринку м'яса \\
та регіону & 2. Рівень розвитку регіонального ринку м'яса \\
\hline Аналіз сучасного стану попиту та & 1. Оцінка сучасного стану споживання м'яса \\
пропозиції на регіональному ринку м'яса & 2. Виявлення споживчих переваг на ринку \\
& 3. Оцінка обсягів виробництва м'яса за категоріями господарств \\
& 4. Оцінка обсягів виробництва окремих видів м'яса \\
& 5. Оцінка факторів, що впливають на обсяг пропозиції м'яса \\
& 6. Співвідношення обсягів сукупної пропозиції та попиту на ринку \\
\hline Оцінка перспектив розвитку регіонального & 1. Визначення внутрішніх регіональних можливостей для збільшення виробництва м'яса \\
ринку м'яса & 2. Складання прогнозу розвитку ринку \\
\hline Дослідження умов функціонування & 1. Дослідження інфраструктурного забезпечення ринку \\
регіонального ринку м'яса & 2. Визначення ступеня державного впливу на ринок \\
\hline
\end{tabular}

В основі запропонованого розрахунку розміру субсидій закладений компенсаційно-витратний підхід, тобто виробнику компенсується різниця між ринковою ціною, яку може оплатити споживач, і необхідними матеріальними витратами на виробництво продукції. Таким чином, розмір субсидії визначається, виходячи з питомої ваги витрат на виробництво і реалізацію продукції, тобто рівень державної підтримки визначається залежно від розміру перевищення собівартості над ціною реалізації.

Розмір субсидії пропонується розраховувати за такою формулою:

$$
P C i=P \Pi i{ }^{*} 3 i^{*} \text { Knodi * Knozi, }
$$

де РСі - розмір субсидії 1-го виду продукції; РПі - обсяг реалізації 1-го виду продукції; Зі - витрати на виробництво одиниці 1-го виду продукції; Кподі - коефіцієнт державної підтримки 1-го виду продукції; іпогі - коефіцієнт зміни поголів'я сільськогосподарських тварин для виробництва 1-го виду продукції. мулою:

Коефіцієнт підтримки розраховується за такою фор-

$$
\text { Кпод = } 1-Ц / C, \text { при Кпод } \geq 0,
$$

де Ц - ціна реалізації 1 т продукції, грн. ; C - собівартість 1 т продукції, грн. формулою:

Коефіцієнт зміни поголів'я розраховується за такою

$$
\text { ino2= Qom4/Qбаз, }
$$

де $Q$ - поголів'я сільськогосподарських тварин[12].

Досить важливою складовою $є$ наявність стимулюючого коефріцієнта, в якості якого використаний коефіцієнт зміни поголів'я сільськогосподарських тварин. Як показав аналіз українського ринку м'яса, скорочення пропозиції м'яса було викликано, більшою мірою, зниженням поголів'я свиней.

3 метою найбільш ефективного розподілу субсидій між сільськогосподарськими підприємствами претендувати на отримання компенсаційних виплат будуть найбільш сильні і адаптовані до ринкових умов підприємства, що сприяє максимальному виключенню заохочення неефективного виробництва.

У регіонах, де особливе місце на ринку м'яса відводиться громадянам, провідним особистим підсобним господарствам, як економічно і соціально важливим суб'єктам ринку, розподіл субсидій даними суб'єктам ринку запропоновано здійснювати через збутові споживчі кооперативи.

Реалізація м'яса громадянами, провідними особистими підсобними господарствами, через збутові споживчі кооперативи дозволить даним формам господарювання досягти паритету з більш великими учасниками ринку, створить рівні умови в отриманні державних субсидій в регіоні.

Застосування запропонованого розподілу субсидій серед сільськогосподарських товаровиробників м'яса дозволить:

- відшкодувати різницю між ціною продажу і собівартістю продукції, тим самим підвищити доходи сільськогосподарських виробників; 
- обґрунтовано виявляти і прогнозувати найбільш вигідну для виробництва продукцію;

- стимулювати збільшення виробництва м'яса за рахунок прямої залежності розміру субсидій від показників, що характеризують ефективність використання виробничого потенціалу;

- створити однакові умови господарювання для всіх виробників м'яса, що сприятиме розвитку здорової конкуренціiі[14].

Практичне застосування запропонованих заходів на території Херсонської області, а також в схожих за рівнем розвитку та спрямованості сільськогосподарського виробництва регіонах, дозволить поліпшити умови господарювання суб'єктів ринку м'яса, більш повно задовольняти потреби населення регіону та країни, в цілому, в даному виді продукції.

Висновки з даного дослідження і перспективи подальших розвідок у даному напрямі. Результати дослідження показали, що ціни на окремі види м'яса не дозволяють сільськогосподарським товаровиробникам здійснювати не тільки розширене, а й просте відтворення. У зв'язку з цим, необхідна розробка додаткових заходів адресної прямої державної підтримки сільськогосподарського виробництва. Однак, в сучасних умовах така ініціатива вельми скрутна. Поперше, це обумовлено обмеженістю бюджетів, а по-друге, це не зовсім вкладається в стратегію розвитку країни, особливо на тлі вступу до Світової Організації Торгівлі (СОТ).

Вивчення м'ясного кластеру в сільськогосподарській галузі, дає змогу просуванню продукції кластерних підприємств на регіональні ринки, що дасть змогу підвищити конкурентоспроможність тваринницької галузі на регіональному рівні. Формування регіонального м'ясного кластеру в Херсонській області може вплинути на конкурентоспроможність у наступних областях, а саме підвищення продуктивності на підприємствах кластера; створення передумов для розвитку інновацій та економічного зростання; наповнення внутрішнього ринку м'ясопродуктами та вихід на світові ринки; стимулювання формування нових підприємств. Результати цього дослідження слід інтерпретувати з точки зору концепції раціонального розподілу виробничих потужностей. Цього можна досягти за допомогою великомасштабного виробництва товарів масового попиту, який буде задовольняти споживачів та виходити на новий рівень рину м'яса. Адже, світовий досвід у цьому контексті показує, що найбільш соціально орієнтованою є інтеграція сільськогосподарського виробництва на кластерній основі, що створює умови для розвитку різних розмірів та правових форм агробізнесу на основі співпраці та державно-приватного партнерства.

\section{Список використаної літератури:}

1.Пуцентейло П. Р. Конкурентоспроможність м'ясного скотарства України: теорія і практика : моногр. / П. Р. Пуцентейло. -Тернопіль : ВПЦ “Економічна думка ТНЕУ”, 2011. -420 с.

2.Гірняк К. М. Теоретичні критерії ефеективності підприємств з виробництва свинини / К.М. Гірняк // Наук. вісн. Львів. нац. ун-ту ветеринарної медицини і біотехнологій імені С. 3. ґжицького. - 2009. - Т. 11, № 2(41), ч. 5. - С. 19.

3.Калінчик М.В. Ефективність виробництва та розвиток ринку свинини / М.В. Калінчик, М.М. Ільчук, Т.М. Одинцова. К.: Нічлава, 2005. -13 c. - C. $27-32$.

4.Мазуренко О. В. Промислове свинарство в умовах сучасного ринку / О. В. Мазуренко // Економіка АПК. - 2016. - № 8.

5.Месель-Веселяк В. Я. Ефрективність господарювання новостворених сільськогосподарських підприємств ринкового спрямування в Україні / В. Я. Месель-Веселяк // Економіка АПК. - 2016. - № 12. - С. 21-33.

6.Оляднічук Н. В. Удосконалення системи бухгалтерського обліку в аграрному секторі економіки через оптимізовані інформаційні масиви / Н. В. Оляднічук // Вісник Харківського національного аграрного університету ім. В. В. Докучаєва. Сер. : Економічні науки. - 2013. - № 7. - С. 181-186.

7.Рибалко В. П. Управління якістю свинини в умовах ї̈ виробництва / В. П. Рибалко, А. А. Гетя // Ветеринарна медицина. - 2010. - Вип. 94. - С. 317-318.

8.Андрійчук В.Г. Економіка аграрних підприємств: підручник / В.Г. Андрійчук. - 2-ге вид., доп. і перероб. - К.: КНЕУ, 2002. $-624 \mathrm{c}$.

9.Горьовий В.П. Менеджмент фермерського господарства /В.П. Горьовий, С.В. Тимчук // Центр навчальної літератури. $-2014 .-366$ c.

10. Вітков М.С. Розвиток інвестиційної політики в сільському господарстві України / М.С. Вітков // Економіка АПК. - 2005. - №1. - C. 54-57.

11. Гірняк К. М. Теоретичні критерії ефективності підприємств з виробництва свинини / К.М. Гірняк // Наук. вісн. Львів. нац. ун-ту ветеринарної медицини і біотехнологій імені С. 3. Ґжицького. - 2009. - Т. 11, № 2(41), ч. 5. - С. 19.

12. Дієсперов В. С. Ефективність виробництва у сільськогосподарському підприємстві : монографрія / В. С. Дієсперов. К. : НHЦ IAE, 2008. - 340 c.

13. Калінчик М.В. Ефективність виробництва та розвиток ринку свинини / М.В. Калінчик, М.М. Ільчук, Т.М. Одинцова. К.: Нічлава, 2005. - 13 c.

14. Збарський В.К. Свинарство - ключова галузь у сільському господарстві України / В. К. Збарський, О. О. Шпак // Агросвіт. - 2016. - № 21. - С. 8-14.

15. Савицька Н.Л. Теоретико-методичні аспекти формування маркетингової політики підприємств на ринку м'яса та м'ясопродуктів / Н. Л. Савицька, О. П. Афанасьєва // Проблеми економіки. - 2015. - № 2. - С. 172-178.

16. Мазуренко О. В. Промислове свинарство в умовах сучасного ринку / О. В. Мазуренко // Економіка АПК. - 2016. - № 8. - C. $27-32$.

17. Ціхановська В. М. Сучасний стан та тенденції розвитку ринку м'яса і м'ясної продукції в Україні / В. М. Ціхановська, О. В. Томчук, О. М. Ціхановська // Сталий розвиток економіки. - 2015. - № 3. - С. 18-27. 
18. Данько Ю. І. Кооперація в системі забезпечення конкурентоспроможності підприємств-виробників свинини [Електронний ресурс] / Ю. І. Данько, І. В. Лозинська // Економіка АПК. - К.: Національний науковий центр «Інститут аграрної економіки», 2012. - № 4. - С. 93-98.

19. Бочарова Ю. Г. Концентрація та конкуренція на світовому ринку м'яса / Ю. Г. Бочарова // Бізнес Інформ. - 2016. № 3. - C. 18-23

20. Пуцентейло П. Р. Конкурентоспроможність м'ясного скотарства України: теорія і практика : моногр. / П. Р. Пуцентейло. -Тернопіль : ВПЦ “Економічна думка ТНЕУ”, 2011. -420 с.

21. Месель-Веселяк В. Я. Ефективність господарювання новостворених сільськогосподарських підприємств ринкового спрямування в Україні / В. Я. Месель-Веселяк // Економіка АПК. - 2016. - № 12. - С. 21-33.

22. Оляднічук Н. В. Удосконалення системи бухгалтерського обліку в аграрному секторі економіки через оптимізовані інформаційні масиви / Н. В. Оляднічук // Вісник Харківського національного аграрного університету ім. В. В. Докучаєва. Сер. : Економічні науки. - 2013. - № 7. - С. 181-186.

23. Рибалко В. П. Управління якістю свинини в умовах її виробництва / В. П. Рибалко, А. А. Гетя // Ветеринарна медицина. - 2010. - Вип. 94. - С. 317-318.

24. Лозинська І. В., Данько Ю. І. Стратегічні пріоритети розвитку скотарства в аграрних підприємствах. Соціально-економічні проблеми сучасного періоду України: зб. наук. пр. 2018. Вип. 1(129). C. 152-157. URL: http://ird.gov.ua/sep/doi/sep2018.01.157_u.php.

Usikova E.N., Dr, Associate Professor, Mykolaiv National Agrarian University (Mykolaiv, Ukraine)

Analysis and use of the meat cluster in the agricultural sector.

In this article, the efficiency of the cluster approach for the development of industrial pig production has been analyzed and investigated. In the article a model of the pig breeding cluster was developed, and the compensation-cost approach and technological chain of production were used. The entry into the meat cluster of enterprises, analysis of the current state of development of the meat market in the Kherson region was investigated. The results of the study showed that prices for certain types of meat do not allow agricultural commodity producers to carry out not only extended but also simple reproduction.

Key words: cluster approach, clusters, self-regulatory organization competitiveness cluster beef, compensation-cost approach, the distribution of subsidies.

Дата надходження до редакції: 06.08.2019 р. 